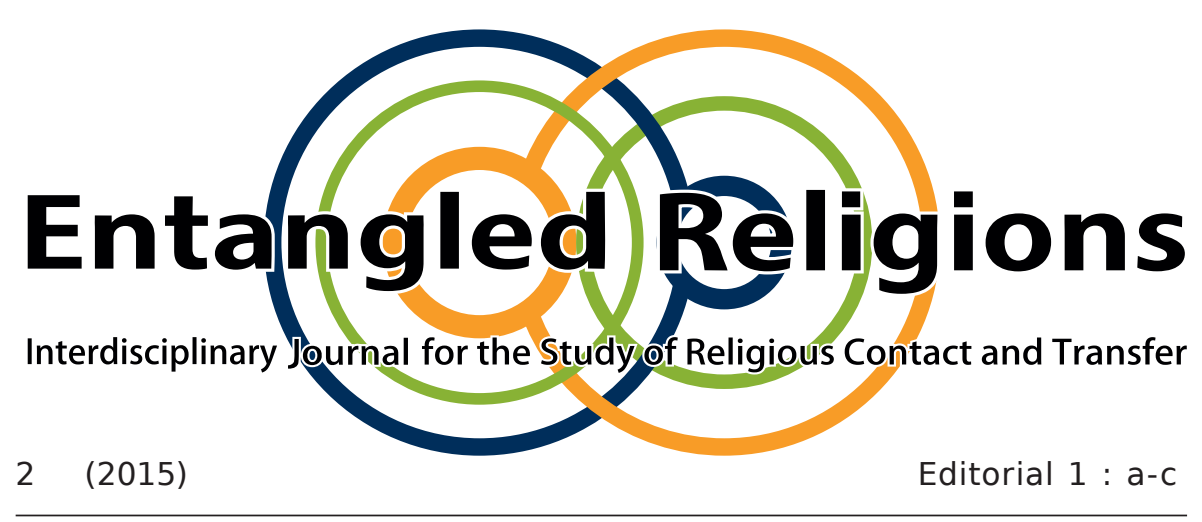

Editorial

Our New Book Reviews Section

VIVIAN STROTMANN

Ruhr-Universität Bochum, Käte Hamburger Kolleg "Dynamics in

the History of Religions between Asia and Europe", Germany

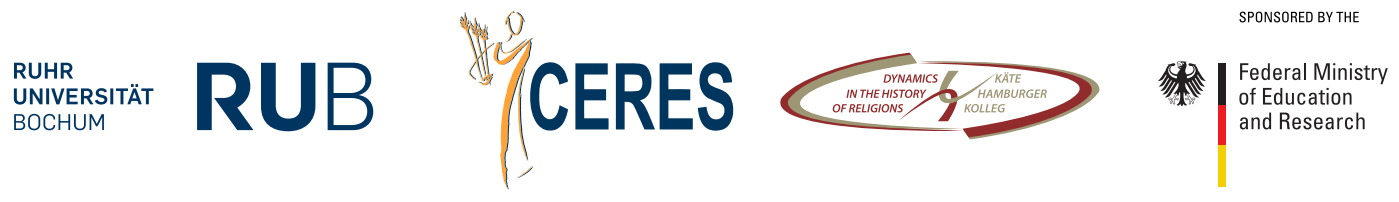




\title{
Editorial
}

\section{Our New Book Reviews Section}

\author{
VIVIAN STROTMANN
}

The year 2015 has arrived and Entangled Religions begins it with a new section. We are pleased to present the first book reviews to our readers. These are

1. Angelika Brodersen: Der unbekannte Kalām. Theologische Positionen der frühen Māturīdīya am Beispiel der Attributenlehre. Berlin / Münster/ Wien/ Zürich/ London: Lit, 2014.

2. Wang Yongbo \& Lothar Ledderose (eds.): Buddhist Stone Sutras in China: Shandong Province, Vol. 1. Hangzhou and Wiesbaden: Harrassowitz and China Academy of Art Press, 2014.

3. Joshua Rodda: Public Religious Disputations in England 1558-1626, St Andrews Studies in Reformation History. Farnham, Surrey: Ashgate, 2014.

Our new book reviews section gives you the opportunity to share your opinion on cutting-edge publications. Books reviewed should therefore not be older than 2 years.

Just as articles, book reviews have to be submitted to Entangled Religions exclusively and must not have been published, before. 
Entangled Religions offers a platform for scholars from all disciplines whose research touches upon matters of religious contact and transfer between the first century C. E. and the present day. We would like our book reviews section to mirror this diversity.

For more details on submission criteria and editorial processing visit our Submission Preparation Checklist and Peer Review Policy information pages - or contact our editorial office at er-contact@rub.de.

We are looking forward to hearing from you! 